\title{
DEVELOPMENT OF WHITE ROT DISEASE IN ONION TRANSPLANTS IN CANTERBURY
}

\author{
J. SWAMINATHAN, K.L. McLEAN and A. STEWART \\ Soil, Plant \& Ecological Sciences Division, Lincoln University, \\ P.O. Box 84, Canterbury, New Zealand
}

\begin{abstract}
White rot disease was monitored in onions grown from transplants in two field sites in Canterbury and compared with disease development in direct seeded crops. Onion seedlings cv. Pukekohe Long Keeper (May and Ryan) were grown in seedling trays ( $25 \mathrm{ml}$ volume) in the glasshouse for 12 weeks and transplanted to the field in August 1999. At both sites onset of disease occurred earlier in onion transplants and was more severe at all assessment times with 60-70\% disease recorded at harvest compared to $1-10 \%$ for direct seeded crops. The benefits of an earlier harvest date for transplanted onions (January compared to March) was outweighed by the higher disease levels.
\end{abstract}

Keywords: onion, white rot, transplants, Canterbury, yield.

\section{INTRODUCTION}

Onion white rot, caused by the soil borne fungus Sclerotium cepivorum Berk., has been present in the Canterbury region since the 1920s and is prevalent in most onion growing sites (Cunningham 1922). The disease first appears in mid December and increases in severity until harvest in February/March. Under conducive weather conditions new infections are evident in February and disease activity can occur up to the day of harvest. Yield losses range from 5-50\% and growers have to implement fungicide spray regimes to keep the disease levels to a minimum. The use of onion transplants may enable growers to bring the harvest date forward by at least four weeks and thereby allow the onion crop to 'avoid' the main peak of white rot activity. Growing onions from transplants may also provide additional yield benefits (Salter 1977). This paper describes two field trials in Canterbury which compare the development of onion white rot disease in onions grown from transplants with direct seeded onions.

\section{Production of transplants}

\section{METHODS}

Onion seeds (Pukekohe Long Keeper, May and Ryan) were planted in seedling trays (135 cells/tray; $25 \mathrm{ml}$ volume/cell) containing vegetable potting mix (Southern Horticultural Products Ltd.). Onion seeds treated with Captan (10 g of product $/ \mathrm{kg}$ seed) to protect against damping-off disease were planted on 16 June 1999 in the trays at the rate of five seeds /cell. Seedling trays were incubated in the glasshouse at $25^{\circ} \mathrm{C}$ for two weeks. Germinated seedlings were thinned to three plants/cell and grown for a further eight weeks. The seedlings were hardened off for seven days in the shadehouse $\left(8^{\circ} \mathrm{C}\right)$ before transplanting into the field.

\section{Trial 1}

The trial was in a field site with a history of white rot disease at Saltwater Creek Rd., North Canterbury. Transplant plugs each containing three seedlings were planted in the field at $25 \times 15 \mathrm{~cm}$ spacing and a depth of $5 \mathrm{~cm}$ on 26 August 1999. Plots were $4 \mathrm{~m}$ long with 5 rows in each plot. Total number of plants per plot was 420 and there was a total of six replicates. Direct seeded plots were planted on 1 November 1999 at the same site adjacent to the transplant plots. Captan treated onion seed (Pukekohe 
Long Keeper, May and Ryan) was planted using a hand-drawn planet junior at a plant spacing of $20 \times 5 \mathrm{~cm}$ with 6 rows per $4 \mathrm{~m}$ plot and six replicates. Total number of plants in each plot was 504. Numbers of white rot infected plants were recorded at fortnightly intervals during the growing season and cumulative percentage disease calculated for each production system. Different planting dates and differing environmental conditions make direct comparison of data invalid.

\section{Trial 2}

The trial was in a naturally infested field site at Springs Road in Lincoln. The experimental protocol and assessment was the same as that described for trial 1 with the exception that transplants were 12 weeks old at time of planting and were planted in $2 \mathrm{~m}$ plots and the direct seeded crop was planted in $6 \mathrm{~m}$ plots. The two production systems were analysed as independant samples using TTEST to compare the difference between the means (Minitab statistical package). The probability levels were determined only for December 1999 and January 2000.

Soil temperature $(10 \mathrm{~cm}$ depth), soil moisture $(10 \mathrm{~cm}$ depth $)$ and total rainfall data were recorded for Lincoln (Trial 2). Soil moisture, measured as volumetric \%, was recorded as a single observation at the trial site every week. The data for soil temperature and rainfall was obtained from the weather station monitored by Crop \& Food Research at Lincoln.

\section{Trial 1}

\section{RESULTS}

Two months after transplanting in the field, the disease was evident in onion transplants in October 1999 (18\%) when the crop was at the bulb expansion stage (bulb diameter $2.5-4.0 \mathrm{~cm})$. The disease incidence slowly increased until January 2000 with a final disease score at harvest of $71 \%$ (Table 1). The disease was not evident in the direct seeded crop until January 2000 (1\%) when the crop was at the 3-4 leaf stage, with an increase in disease incidence to $10 \%$ at harvest in March.

TABLE 1: Cumulative percentage white rot disease in transplanted and direct seeded onions in two trials in Canterbury during 1999/2000.

\begin{tabular}{clrrrrrr}
\hline \multirow{2}{*}{ Trial No. } & Treatment & Oct & Nov & Dec & Jan & Feb & Mar \\
\hline \multirow{2}{*}{1} & Transplants & 18 & 30 & 49 & 71 & - & - \\
\multirow{2}{*}{2} & Direct & -2 & 0 & 0 & 1 & 3 & 10 \\
& Transplants & 0 & 0 & 7 & 70 & - & - \\
$\mathrm{P}<0.05$ & Direct & 0 & 0.4 & 1 & 10 & 70 & - \\
\hline
\end{tabular}

${ }^{1}$ Average of 6 replicates.

${ }^{2}$ No data - direct seeded crop not planted or transplanted/direct seeded crop harvested.

\section{Trial 2}

Disease was first observed in transplants during December $1999(7 \%)$, when bulb diameter was $2.5-4.0 \mathrm{~cm}$. Disease incidence increased to $70 \%$ at harvest in January 2000 (Table 1, Fig. 1a). Disease symptoms were observed in the direct seeded crop during November $1999(0.4 \%)$ when the crop was at the 1-2 true leaf stage. There were few new infections recorded in December and January but a rapid increase in disease levels occurred in February 2000. Final disease incidence at harvest was 70\%. For the December and January assessment times, disease levels recorded in the transplants were significantly higher $(\mathrm{P}<0.05)$ than that recorded for the direct seeded plots (Table 1, Fig. 1a). However, when disease incidence was related to crop phenological stage, there was no difference between the transplanted and direct seeded crops (Fig. 1b).

Soil moisture was $>10 \%$ at all observation times with the highest moisture level of $18 \%$ recorded during January 2000 (Table 2). Average soil temperature was $<18^{\circ} \mathrm{C}$ 

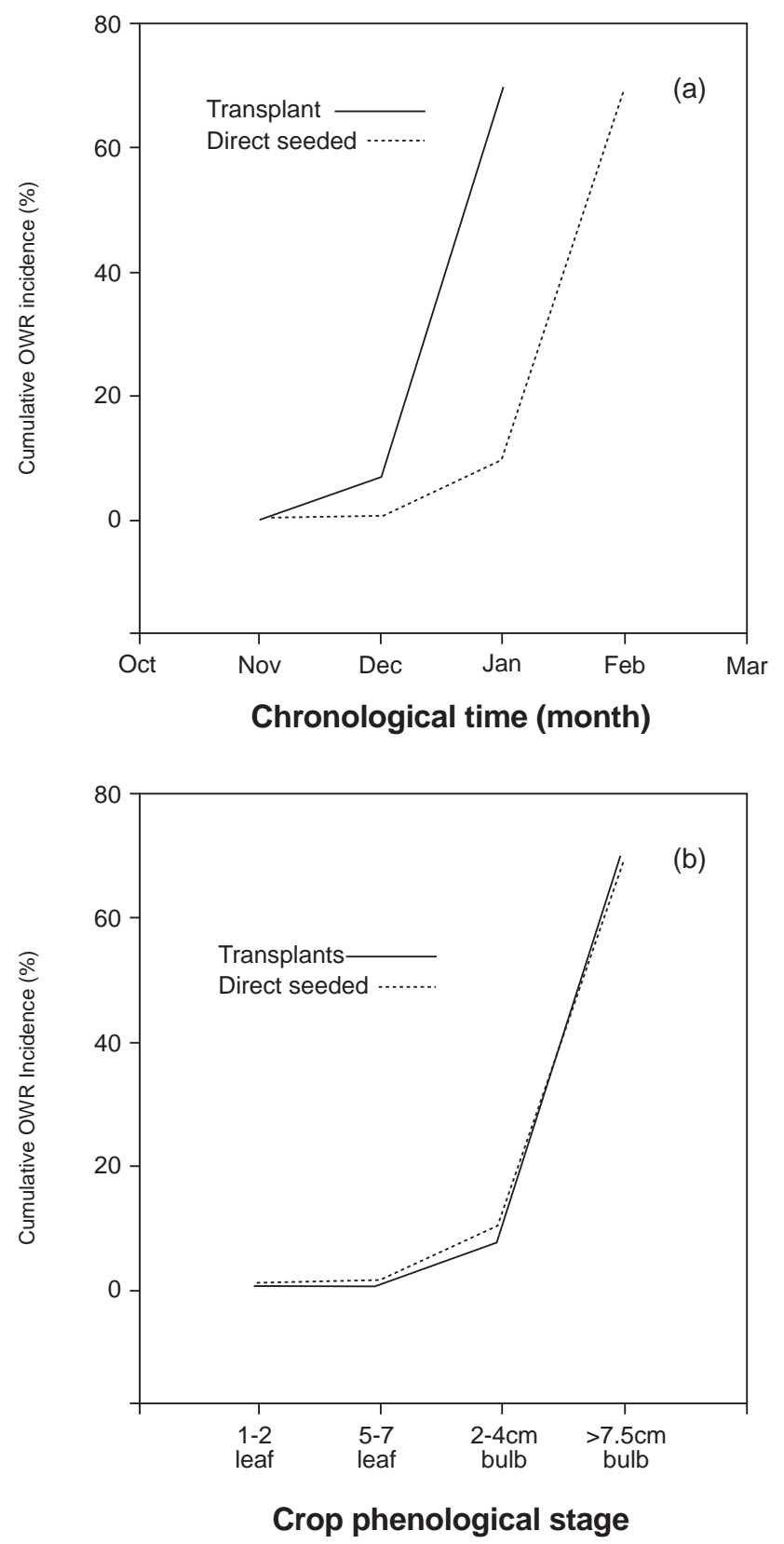

FIGURE 1: Cumulative onion white rot incidence in transplanted and direct seeded onions at Springs Road, Lincoln (Trial 2) (a) disease incidence related to time and (b) disease incidence related to crop phenology. 
during the growing season. Total rainfall of $85 \mathrm{~mm}$ was recorded during January 2000 .

TABLE 2: Soil temperature, moisture and rainfall data recorded at Lincoln (Trial 2).

\begin{tabular}{lccc}
\hline Month & $\begin{array}{c}\text { Average soil } \\
\text { temperature } \\
\left({ }^{\circ} \mathrm{C}\right)\end{array}$ & $\begin{array}{c}\text { Total } \\
\text { rainfall } \\
(\mathrm{mm})\end{array}$ & $\begin{array}{c}\text { Average soil } \\
\text { moisture } \\
(\text { volumetric \%) }\end{array}$ \\
\hline October 1999 & 12.3 & 50.9 & 13.0 \\
November 1999 & 14.2 & 60.5 & 14.1 \\
December 1999 & 15.8 & 35.1 & 17.2 \\
January 2000 & 17.4 & 85.0 & 18.4 \\
February 2000 & 17.4 & 19.9 & 15.8 \\
\hline
\end{tabular}

\section{DISCUSSION}

White rot disease levels were higher than normal in the Canterbury region during the 1999/2000 growing season. This was due to the unusually cool, wet weather over the December-February period which maintained soil temperatures and moisture within the range conducive for white rot infection. It is evident from the disease scores that the transplants succumbed to disease more readily than the direct seeded crop. It is possible that the high soil moisture content and stage of crop development in the transplanted crop may have resulted in optimum release of volatile sulphur compounds from the onion roots which are known to stimulate the germination of pathogen sclerotia. Overseas research has shown that high soil moisture, created by regular crop irrigation in a dry area, increased the total volatile sulphur content of onion bulbs (Rajas et al. 1992). It is possible that when soil temperature and moisture conditions are conducive for sclerotial germination (as recorded for trial 2), the extent of infection is likely to be determined by the level of stimulatory sulphur compounds released from the onion roots, which is related to the developmental stage of the plant. At a single time point, for example January, white rot infection of transplants was 60-70\% compared to only $1-10 \%$ in the direct seeded crops. Phenologically, the transplants were at bulb expansion stage with root exudation likely to be at a maximum, whilst the direct seeded plants were only at the 4-7 true leaf stage.

The use of onion transplants is not a feasible option to help manage onion white rot disease in Canterbury. In the absence of disease, it is possible that an earlier harvest date and possible yield benefit may be considered advantageous by growers (Rickard 1977). However, the cost of producing transplants and the extra mechanisation involved is likely to act as a deterrent for most growers. The interesting biological consequence of this work is the realisation of the importance of the bulb developmental stage in determining infection levels when environmental conditions are favourable for disease. Clearly this parameter should be considered an integral component of any predictive model that may be developed for onion white rot disease. Future work should examine the profile of sulphur compounds released from onion roots during the growing season and their relationship with sclerotial germination and plant root infection by the white rot pathogen.

\section{REFERENCES}

Cunningham, G. H., 1922. Some recent changes in the names of plant-diseases. Pat II and III. N.Z. J. Crop. Hort. Sci. 24: 37-45.

Rajas, R.N., Ghulaxe, S.N. and Tayde, S. R., 1992. Study of different levels of sulphur, spacing and frequencies of irrigation on total volatile sulphur content of onion. J. Soils \& Crops 2: 66-68.

Rickard, P., 1977. Yields up, costs cut with multi-plant mini-blocks. Grower 87: 20, 1094, 1096.

Salter, P.J. 1977. Is transplanting the answer to higher yields of sown onions? Hort. Ind. July: 508-509. 